\section{ASTRONOMICAL NOTES}

New Comet.-A new comet, discovered by Mr. Brooks, has been observed by Mr. Wendell, of Harvard College Observatory, and Mr. Ainslie Common, of Ealing. On Friday night its approximate position was R.A. I3h. $53 \mathrm{~m}$., and N.P.D. $52^{\circ} 20^{\prime}$. Its R.A. is increasing and N.P.D. decreasing; diameter, 9 minutes of arc, and getting brighter.

New Minor Planet,-On the evening of the 3 rd inst. Herr Palisa, of Vienna, discovered a minor planet, thus bringing the number of these bodies to 250 . The following are the particulars of the discovery:-September 3, 9h. 53s. (Greenwich mean time); right ascension, $23 \mathrm{~h}$. $34 \mathrm{~m}$. $44 \mathrm{~s}$. ; north polar distance, ro $^{\circ} 9^{\prime} 35^{\prime \prime}$; daily motion in right ascension, $48 \mathrm{~s}$. decreasing, in polar distance $3^{\prime}$ increasing; magnitude, rrth.

\section{GEOGRAPHICAL NOTES}

THE Caroline Islands, which are attracting so much political attention now, are described at some length in the Gazette Géographique. It is generally acknowledged that they were liscovered by a Portuguese navigator in 1526, and during the rest of the sixteenth century they were frequently visited by Spanish and Portuguese explorers. They were called the Carolines about $\mathbf{I} 686$ by a pilot named Lezcano, who saw many islets there, but could not tell to what group they belonged, or indicate their exact position. The name was given to them after Charles II. ; they have also been called the New Philippines, but this has never prevailed. Towards the end of the seventeenth century the Spaniards in the Philippines and Mariannes learned something of the Carolines, and in 1705 an imperfect map of the group was sent to Pope Clement XI., and then the Jesuits of the mission at Manila resolved to establish a branch in the Carolines. In I7 Io the missionaries and a few soldiers set sail, but on arriving at the Pelews were all massacred. Up to 1817 the Carolines were visited by navigators of all nations, but the number of the islands, their exact position, and the hydrography of the seas in which they were situated, was totally unknown. In that year Kotzebue, and subsequently Freycinet, Duperrey, Dumont d'Urville, and others, visited the whole of the Archipclago, and from them we got our first accurate accounts of the Carolines and their inhabitants. The Caroline archipelago forms part of Micronesia, and is situated to the south of the Ladrones, to the west of the Marshalls, and to the north of New Guinea. It consists of about 500 islands, of which the greater number are only atolls. The number of real islands is only forty-eight, but as each of these is surrounded by a certain number of islets, it may be said that the archipelago consists of forty-eight groups; forty-three of these are low coral islands, while five are composed of basalt with coral at the base. The superficial area over which the archipelago is spread is about fortyfive square leagues. Geographically it may be divided into three main groups, separated by two large channels : the eastern group, of 'which the principal island is Ascension or Ponape; the central group, and the western group, the principal island being Eap or Jap, of which much is being heard just now. Ponape is between 50 and 60 miles round, and has a peak in the centre which rises to a height of 2860 feet. At one part of its coast there are curious ruins which are still a problem for ethnologists; they are apparently the remains of a large building constructed of huge blocks of basalt. The archipelago, although close to the equator, enjoys a temperate climate; there are two rainy seasons - one in January, the other in August. The islands are of astonishing fertility; the principal productions are the bread-fruit, cocoa-nut, the palm, bamboo, orange, and clove tree, sugar-cane, beetle, sweet potato, \&c. The population is generally estimated at I8,000 to 20,000 , and belongs ethnologically to the Micronesian family. The principal elements are Malay and Maori ; but there is also a mixture of Negrito and Papuan, to which in later times was added a Chinese and Japanese element. The language is as mixed as the race; the grammatical constructions are the same as those of the Maori, but Malay influence is also evident. In some of the islands there are two languages, as in Java-the vulgar and polished. They have no religion properly so-called; they believe in spirits, which are the souls of their deceased ancestors, and they have a great respect, a kind of cult for their dead, whom they preserve till the body falls to pieces. As in all the islands of the Pacific, tabu is practised. Each group of islands is governed by a chief or king. His power in time of peace is purely nominal, but he enjoys the respect of all ; but in the frequent bloody wars his authority is unbounded, and all submit blindly to his will.

ThE Pelews or Palaos Islands are quite distinct from the Carolines; they are the most western islands of Micronesia, and are situated about 600 miles east of the Philippines. The archipelago consists of ten principal islands and a number of islets. The principal one, called Babelthuap, is 30 miles long, the southern part being very mountainous. All the islands are covered by thick forcsts, the trees of which are used by the natives to construct their large canoes. Besides the yam and the cocoa-nut there are also bananas, oranges, and a large number of nutritious roots. The population is about 3500 souls, belonging to a race which is quite distinct from the Caroline. Islanders. They present all the characteristics of the Malay and Papuan races, and are probably the result of the mixture of a superior Malay tribe with an inferior aboriginal people. Old travellers speak very well of these natives : they are said to be in every way superior to the inhabitants of the Caroline Islands. Here also there are two languages : one for addressing superiors, the other inferiors; possibly it would be more correct to say that there is only one language, with copious honorific forms. The king has instituted an order, which he gives or withdraws at his pleasure: the insignia is the first cervical vertebra of the fish dugong.

THE Rundschau fïr Geographie und Statistik for September reproduces a forgotten discourse of Alexander von Humboldt. It was never published, although it was privately printed for the use of the members of the Society before whom it was delivered. It deals with the primitive peoples of America and the monuments which they have left behind them, and was delivered before the Philomatic Society of Berlin in January, $\mathbf{1} 806$; that is a few months after his return from his travels. It had grown to be a bibliographical curiosity; part of its contents was afterwards reproduced in his "Ansichten der Natur" and "Vues des Cordilleres," and later investigations have materially altered some positions taken up; but the discoursc is otherwise very interesting, especially after its disappearance for nearly eighty years.

\section{CONTENTS}

PAGE

Our Present Needs . . . . . . . . . . . . . 433

The "Decomposition" of Didymium . . . . . 435

Our Book Shelf :-

Dagincourt's " Annuaire géologique universel et Guide

du Géologie autour de la Terre" . . . . . . .

Letters to the Editor :-

The Meteoric Cycle and Stonehenge.-R. Edmonds

Nebula in Andromeda. - Lord Rosse, F.R.S.

Sunsets.-R. McLachlan, F.R.S.

Pulsation in the Veins. - S. W.

Red Hail.-Prof. Theodore Schwedoff

On the Terminology of the Mathematical Theory of

Electricity.-Henry Muirhead . . . . . . .

The British Association . . . . . . . . . . . 437

Inaugural Address by the Right Hon. Sir Lyon

Playfair, K.C.B., M.P., F.R.S., President . .

Section A-Mathematical and Physical ScienceOpening Address by Prof. G. Chrystal, M.A.,

F.R.S.E., President of the Section . . . . .

Section B-Chemical Science-Opening Address by

Prof. Henry E. Armstrong, Ph.D., F.R.S.,

Sec.C.S., President of the Section . . . . . .

Section $\mathrm{C}-$ Geology-Opening Address by Prof. J. W. Judd, F.R.S., Sec.G.S., President of the

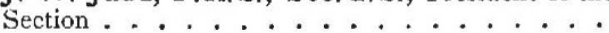

Notes for the Opening of a Discussion on Electrolysis, to be held in Section $B$, at the British Association in Aberdeen, September, 1885, by Professor Oliver Lodge . . . . . . . . . Notes . . . . . . . . . . . . . .

Astronomical Phenomena for the Week 1885 ,

September 13-19............. Astronomical Notes :-

New Comet ....... . . . . . . . 464

New Minor Planet . . . . . . . . . . . . 464

Geographical Notes .......... . 464 